\title{
PREVIOUS EXPERIENCE OF UNIVERSITY STUDENTS IN PHYSICAL EDUCATION AT HIGH SCHOOL
}

\author{
Eleonora Šišlova \\ Riga Technical University, Latvia \\ Andra Fernāte \\ Latvian Academy of Sport Education, Latvia
}

\begin{abstract}
Students in Latvia have a moderately positive attitude towards organized physical activity at the university, it has been formed in the past and is related to the previous experience in physical education gained at school. To promote student involvement in physical activities and changes in students' attitude towards physical activity at the university, it is necessary to evaluate their previous experience in physical education acquired at school. The aim of the study is to evaluate of the psychometric properties of the Youth Experiences Survey for Sport (YES-S) (MacDonald et.al., 2012) for students of Latvia. Research methods: The Youth Experiences Survey for Sport (YES-S), Principal component factor analysis. Respondents: 265 students aged from 19 to 24 from four universities of Latvia. Some contradictions were identified between the theoretical basis of the YES-S instrument's scale and the various criteria that can characterize experience in physical education. As a result, a five-factor structure was developed, which includes 19 items. The factor loads of the other 18 items indicated that these items were not compatible with the theoretical concept of the YES-S.
\end{abstract}

Keywords: physical education, previous experience in sport, university students.

\section{Introduction}

In Latvia, there is a moderately positive attitude towards compulsory sport activity at the university (Koroḷova, 2010; Vecenāne \& Fernāte, 2012; Šišlova \& Fernāte, 2016). In Planned Behaviour Theory (PBT), an attitude towards a particular activity is a specific action (Ajzen, 1991). For students in Latvia, the activity in attending physical activities at the university is not unambiguous: organized physical activities, if they are not compulsory, are attended by only $36 \%$ of students (Korolova, 2010), in order not to attend the compulsory sport activities, $13 \%$ of students submit medical certificates, where the exemption from sport is not justified; moreover, it has been determined that this action comes from school and these students mostly had a negative attitude towards physical education at school (Šišlova \& Fernāte, 2017). Differences in the attitudes of students towards physical education may be attributed to the previous experience 
in physical education (Subramaniama \& Silverman, 2007). Certain correlation has been determined between attitude towards physical education at high school and at university (Шишлова \& Дунай, 2017). Thus, the attitude towards physical activities at the university is formed in the past and is related to the experience gained in physical education at school. To improve students' attitude towards physical activity at the university, it is necessary to evaluate their experience in physical education at school. The aim of the study is to evaluate of the psychometric properties of the Youth Experiences Survey for Sport (YES-S) (MacDonald et.al., 2012) for students of Latvia. Method: participants were 265 students aged from 19 to 24 from four universities of Latvia who completed the Youth Experiences Scale (YES-S), Principal component factor analysis was carried out.

\section{Theoretical review}

The YES-S is a five-factor experience measure specifically designed for the sport context. The 37 items of the YES-S instrument were divided into five scales. Four scales measure the positive developing experience, while one scale measures the negative experience (MacDonald et al., 2012). MacDonald and co-authors (2012) believe that the positive and negative results of participation depend on many factors. After examining several researches, it was concluded that if the sport environment is not created carefully, participants may experience both positive and negative results; thus, the scale of the instrument is based on a series of positive and negative influencing results, which are related to participation in organized sports (MacDonald et al., 2012). The concepts of the scales are outlined below.

One of the more spacious scales - "Personal \& Social skills" - includes 14 items. Based on various researches, MacDonald and co-authors (2012) believe that the experience gained in organized sport activity may be applicable in other aspects of life. For example, team work in a work environment that requires good communication skills, cooperation, as well as knowledge how to help others and compromise. The scale includes items that are related to personality developing moments, which can be gained by youth through sport - knowledge of leadership and of the influence of an individual's emotions and attitudes, as well as giving and taking of feedback (MacDonald et al., 2012).

The scale "Cognitive skills" includes 5 items, which are not directly related to the development of physical skills and abilities; however, MacDonald and coauthors (2012) based on researches, that it is possible to develop both cognitive and creative skills in a sport environment, as well as that engaging in sport 
increases academic performance and the desire to stay in school (Dwyer et al., 2001; Eccles \& Barber, 1999).

The scale "Goals setting" includes four items. According on the fact that athletes often set specific goals in the field of sport (Burton \& Weiss, 2008), the authors of the YES-S instrument believe that the scale "Goals setting" may be useful for evaluating various programs in sport, assessing the items of the scale to determine behavioural changes. Moreover, coaches interested in goal setting in a sport may use this construction to determine an athlete's progress or development (MacDonald et al., 2012).

The four items of the scale "Initiative” are based on Larson's (2000) concept that structured voluntarily activity is most suitable for the development of initiative, for instance, sport, art, or other activities, where youth tends to combine motivated activity with focused attention. The authors of the YES-S instrument emphasize that high evaluations of all four items of the scale "Initiative" mean constructive initiative (MacDonald et al., 2012).

The scale "Negative experience" includes ten items. By reviewing sources of literature, the authors of the instrument conclude that engaging in sport can have a negative impact on physical health and well-being, as well as psychological, emotional, and social development, which corresponds with the concept presented by Fraser-Thomas and co-authors (2005) on the possibility of negative impact in sport on three levels. The proposed items of the scale for negative experience indicate the flexibility of the scale to cover several age groups (MacDonald et al., 2012).

Do all the mentioned items characterize experience in physical education? Are there no theoretical contradictions in the proposed scales?

No contradictions were found in the scale "Personal \& Social skills". Several criteria of the scale were marked as positive experience in sport - peer interactions, new social contacts, friendship, support from adolescents, support from the family (Alender et al., 2006; Strean, 2009). It is a well-known fact that feedback has a very significant impact on a student's learning achievements (Hattie, 2009).

Some contradictions can be observed in the scale "Cognitive skills", which assesses the improvement of computer/internet skills, acquisition of information, academic, and creative skills through engaging in sport. Physical activity improves academic skills (Hoseinzadeh \& Shoghi, 2013). However, these items may raise questions of how they are related to experience in sport or physical education, because "Physical activity, physical education and school sport are similar in that they all include physical movement..." (Health position paper, 2015). The mentioned skills can be considered as benefits obtained through participation in sport or physical education; however, benefits of sport activities may also include such criteria as improvement of physical fitness, strengthening 
of health, development of new skills and improvement of the previously acquired skills, and others which are related to students' attitude towards compulsory physical activity at the university (Šišlova \& Fernāte, 2015).

At the same time, the item "Improved athletic or physical skills" was included in the scale "Initiative". However, the modified construction of the YES 2 instrument for assessing youth's experience in any structured activity, which is the basis of YES-S, this item relates to the scale "Cognitive skills" (Hansen \& Larson, 2005).

The scale "Goals setting" did not cause many contradictions. Setting personal goals increases the motivation to participate in physical activities (Flintoff \& Scraton, 2001; 2012; Lewis, 2014). Traditionally, it was considered that all activities are given meaning, direction, and purpose, and that the quality and intensity of behaviour will change as these goals change (Covington, 2000).

Some contradictions can be observed in the scale "Negative experience". In the world, research on experience in physical education revealed causes related to experienced emotions that influence a person's participation or non-participation in physical activity. The negative influencing factors were peer pressure; low support from teachers; dominance of the best students; team selection based on skills and abilities, which humiliates; aggressive behaviour supported by coaches and teachers; teachers' verbal abuse; mocking; unfairness of both adults and peers in sports games; exclusion; low skills; feeling of failure; being afraid; focusing attention on competitions, wins, the best team, but not on youth education and health; an assessment system based on physical performance, which forces lessskilled students to do something they may not do, even threatening them with a bad mark (Flintoff \& Scraton, 2001; Allender et al., 2006; Brooks \& Magnusson, 2006; Strean, 2009, Beltrán-Carrillo et al., 2012, Cardinal et al., 2013). Several of these criteria are items of the classroom climate, which is created by teachers (Lewis, 2014). In Latvia, students do not want to attend sport activities mainly due to having to pass the norm, even though the standard of physical education does not provide for this. Students are also dissatisfied with evaluation, difficult tasks, teachers' attitude towards „losers”, boring and repetitive classes, insufficient skills (Rubana \& Ābele, 2008). Although several items of the proposed scale are similar with the mentioned criteria, items related to adult behaviour that do not fit youth's beliefs on morality or their own immoral behaviour, or the use of alcohol or drugs causes doubts as to whether or not they are necessary for the determination of students' experience in physical education. 
SOCIETY. INTEGRATION. EDUCATION

Proceedings of the International Scientific Conference. Volume I, May $25^{\text {th }}-26^{\text {th }}$, 2018. 524-535

\section{Material and methods}

The pilot research involved 265 students aged from 18 to $24(21.5 \pm 2.1)$ from four universities of Latvia: Riga Technical University (RTU), University of Latvia (UL), Jāzeps Vītols Latvian Academy of Music (JVLAM) and Latvia University of Agriculture (LUA) (Table 1).

Table 1 Selection of University Students of Latvia

\begin{tabular}{|l|c|c|c|c|c|}
\hline & RTU & UL & JVLAM & LUA & $\sum$ \\
\hline & 132 & 88 & 21 & 24 & 265 \\
\hline Men & 72 & 49 & 13 & & 134 \\
\hline Women & 60 & 39 & 8 & 24 & 131 \\
\hline
\end{tabular}

The students voluntarily and anonymously participated in a The Youth Experiences Survey for Sport. The stage of high school was chosen so that the events in physical education in the past would be closer to the present, although the physical education and sport environment provides an opportunity for the creation of long-term memory, especially if the memory about them is a bad one (Cardinal et al., 2013).

In the questionnaire, the YES-S instrument was proposed for evaluation, which consists of 37 items, which are divided into five scales. Four scales assess the positive developing experience: "Personal \& social skills", “Cognitive skills”, "Goals setting", "Initiative", - a total of 27 items, but one scale assess the "Negative experience" - 10 items. At the RTU language centre the statements were translated from English into Latvian and back into the original language. A 4-point Likert scale was adopted for the evaluation of the items of the YES-S instrument, where 1 - completely disagree, 2 - disagree, 3 - agree, 4 - completely agree (MacDonald et al., 2012).

Descriptive mathematical statistics was applied - arithmetic mean, standard deviation, as well as principal component analysis (PCA), where the distributed factors can explain the whole dispersion - common and specific, was applied for the result processing, as well as Varimax rotation method with Kaiser normalization. The reliability of the scale was evaluated according to the Cronbah's alpha indicator: $\alpha>0.9$ - Very good, $\alpha>0.8$ - Good, $\alpha>0.7$ - Acceptable, $\alpha>0.6$ - Questionable, $\alpha>0.5$ - Bad, and $\alpha<0.5$ - Unacceptable (George and Mallery, 2003, p. 231). Criterion of statistical reliability $\mathrm{p}<0.05$. The results were processed using the Statistical Package for the Social Sciences (SPSS) version 23.0. 


\section{Results}

37 items were tested to determine the factor structure, determining 5 factors for analysis according to the YES-S instrument (MacDonald et al., 2012). The Kaiser-Meyer-Olkin (KMO) indicator of sampling adequacy was 0.839. The indicator of the Bartlett's sphericity test (BST) was significant, $\chi 2=6195.397$, $\mathrm{p}<0,0001$. These results indicated that the sample size was sufficient in relation to the number of items of the YES-S, as well as that the correlations between the items significantly differed from zero and the items was suitable for factor distribution. Scree plot indicated that a 5-factor structure may be applicable for this analysis. The obtained five factors explained 55.19\% of the dispersion data. The Cronbach's alpha indicators of internal consistency of the factors are shown in Table 2.

Table 2 Internal consistency (Cronbach Alfa) of the facors

\begin{tabular}{|c|c|c|c|c|}
\hline Factor 1 & Factor 2 & Factor 3 & Factor 4 & Factor 5 \\
\hline 13 items & 11 items & 6 items & 4 items & 3 items \\
\hline 0.908 & 0.918 & 0.804 & 0.422 & 0.579 \\
\hline
\end{tabular}

The internal consistency for the first three factor's scales was acceptable, but for the $4^{\text {th }}$ and the $5^{\text {th }}$ factor's scale - unacceptable (George and Mallery, 2003, p. 231). Only factors 2 and 3 were successfully interpreted in the obtained structure, where items were combined according to the YES-S scales "Personal \& Social skills" and "Negative experience". Interpretation of factors 2, 4 and 5 was difficult. Consequently, item loading analysis was carried out based on two main criteria - the size of the item loading and cross-loading, as well as the conceptual coherence of the items with the factors that they load in terms of factor interpretation (Costello \& Osborne, 2005). The minimal item loading of 0.319 was calculated by the formula: FL min= 5.152/[SQRT(N-2)] (Norman \& Streiner, 1994, p. 139).

Thus, items with a loading below 0.319 and items with cross-loading in other factors above 0.319 , as well as items that make factor interpretation difficult were removed. Thus, 17 items were removed from the questionnaire. There was left one criteria with cross loads above 0.319 in the structure, because it is well suitable for the scale concept. The remaining 20 items created a well-interpretable 5 -factor structure (Table 3). Scree plot indicated that a 5-factor structure may be appropriate for this analysis. 
SOCIETY. INTEGRATION. EDUCATION

Proceedings of the International Scientific Conference. Volume I, May 25 ${ }^{\text {th }}-26^{\text {th }}$, 2018. 524-535

Table 3 Factor loadings of items

\begin{tabular}{|c|c|c|c|c|c|c|}
\hline & & 1. & 2. & 3. & 4. & 5. \\
\hline 1. & Made a new friend & 0.811 & & & & \\
\hline 2. & $\begin{array}{l}\text { Learned I had a lot in common with } \\
\text { people from different backgrounds }\end{array}$ & 0.795 & & & & \\
\hline 3. & Got to know people in the community & 0.786 & & & & \\
\hline 4. & $\begin{array}{l}\text { Learned to be patient with other } \\
\text { group members }\end{array}$ & 0.784 & & & & \\
\hline 5. & Learned about helping others & 0.742 & & & & \\
\hline 6. & $\begin{array}{l}\text { Learned that is not necessary to like } \\
\text { people in order to work with them }\end{array}$ & 0.726 & & & & \\
\hline 7. & There were cliques in this activity & & 0.814 & & & \\
\hline 8. & $\begin{array}{l}\text { Other youth in this activity made } \\
\text { inappropriate sexual comments, } \\
\text { jokes, or gestures }\end{array}$ & & 0.798 & & & \\
\hline 9. & $\begin{array}{l}\text { Adult leaders made personal } \\
\text { comments that made me mad }\end{array}$ & & 0.738 & & & \\
\hline 10. & $\begin{array}{l}\text { Was treated differently because of my } \\
\text { gender, race, ethnicity, disability, or } \\
\text { sexual orientation }\end{array}$ & & 0.650 & & & \\
\hline 11. & $\begin{array}{l}\text { Adult leaders encouraged me to do } \\
\text { something I believed morally wrong }\end{array}$ & & 0.619 & & & \\
\hline 12. & This activity has stressed me out & & 0.568 & & & \\
\hline 13. & $\begin{array}{l}\text { Learned to consider challenges when } \\
\text { making future plans }\end{array}$ & & & 0.886 & & \\
\hline 14. & $\begin{array}{l}\text { Observed how others solved } \\
\text { problems and learned from them }\end{array}$ & & & 0.814 & & \\
\hline 15. & I set goals for myself in this activity & & & 0.787 & & \\
\hline 16. & $\begin{array}{l}\text { Learned to find ways to reach my } \\
\text { goals }\end{array}$ & 0.348 & & 0.751 & & \\
\hline 17. & I became better at giving feedback & & & & 0.927 & \\
\hline 18 & I became better at taking feedback & & & & 0.908 & \\
\hline \multirow[t]{2}{*}{19.} & I put all my energy into this activity & & & & & 0.783 \\
\hline & Learned to push myself & & & & & 0.778 \\
\hline \multicolumn{2}{|r|}{$\alpha$} & 0.892 & 0.804 & 0.886 & 0.778 & 0.856 \\
\hline \multirow{2}{*}{\multicolumn{2}{|c|}{$\begin{array}{r}\text { Standartized items } \alpha \\
\text { Mean }\end{array}$}} & 0.892 & 0.808 & 0.885 & 0.783 & 0.858 \\
\hline & & 13.29 & 12.64 & 9.31 & 4.51 & 5.43 \\
\hline \multicolumn{2}{|r|}{ SD } & 4.23 & 4.06 & 3.13 & 1.47 & 1.57 \\
\hline \multicolumn{2}{|r|}{$F$} & 44.38 & 104.34 & 78.13 & 12.42 & 12.10 \\
\hline \multicolumn{2}{|r|}{$\mathrm{p}$} & 0.000 & 0.000 & 0.000 & 0.001 & 0,001 \\
\hline \multicolumn{2}{|r|}{ Grand Mean } & 2.23 & 2.11 & 2.33 & 2.25 & 2.72 \\
\hline
\end{tabular}


The KMO indicator of sampling adequacy was 0.793. The indicator of BTS was significant, $\chi 2=2993.249, p<0,0001$. The obtained 5 factors explained $69.55 \%$ of the dispersion data. The item loadings were sufficiently high, which indicated that the created scales are related to the YES-S scales and they have the same theoretical basis. The Cronbach's alpha indicators of internal consistency of all scales was good and acceptable (Table 3).

The means of the items are reflected graphically. The item numbers correspond to the item numbers from Table 3 (Figure 1).

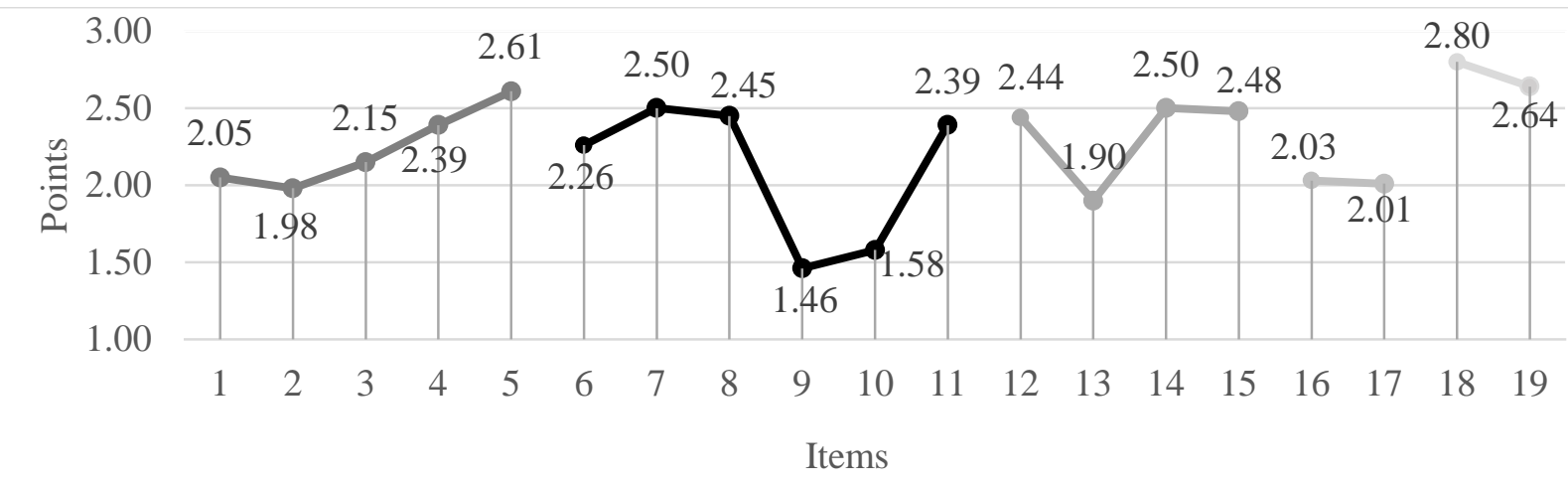

Figure 1. Average results of item evaluation on a 4-point scale

As it can be observed, the evaluations of the 4 items of factor "Negative experience" were assessed sufficiently high in comparison to several items from the four positive experience scales (Fig.1).

The created structure differed from the proposed YES-S structure (Fig.2).

\begin{tabular}{|c|c|}
\hline YES-S original \\
\hline Personal \& Social skils \\
\hline Cognitive skills \\
\hline Goals setting \\
\hline Initiative \\
\hline Negative experience
\end{tabular}

Figure 2. Structures of factors

It was not included the factor "Cognitive skills", as well as the obtained factors split MacDonald's and co-authors (2012) concept of personal and social skills. According to the results, 2 factors were obtained called "Social skills" and "Feedback". The factors "Negative experience", "Goals setting" and "Initiative" were obtained similarly to the YES-S factor structure. 


\section{Discussion}

The experience of students in Latvia in physical education was evaluated, using the YES-S. As a result, a 5-factor structure was created with reliable scales, which included 20 items that had the same theoretical basis of the mentioned instrument. However, in the new structure were not included 17 items, whose factor loading indicated the inadequacy of these items to the theoretical concept of the YES-S instrument.

The created structure was not included the factor "Cognitive skills". The 5 items of the YES-S scale "Cognitive skills" are not directly related to the development of physical skills and abilities (e. g. computer/internet and creative skills, the desire to stay in school). The phenomenon of the results showed that students in Latvia were not associated the mentioned skills with physical education, or do not considered them as essential skills that are formed in sport activities. Although, a sport environment provides an opportunity to develop both cognitive and creative skills, as well as that engaging in sport increases academic performance and the desire to stay in school (Dwyer et al., 2001; Eccles \& Barber, 1999), and also, improves academic achievements (Hoseinzadeh \& Shoghi, 2013). Meanwhile, the benefits of sport activity can include improvement of physical fitness, strengthening of health, development of new skills and other, which is related to the students' attitude towards compulsory physical activity at the university (Šišlova \& Fernāte, 2015). So, the question of whether the scale "Cognitive skills" evaluates the experience of students in Latvia in physical education remained questionable.

At the same time, the item "Improvement of athletic or physical skills" was removed from the new structure's scale "Initiative", which suggested that students in Latvia were not regarded the mentioned item as an item of initiative. In the primary factor structure this item with cross-loading was combined in the first factor with items that, according to MacDonald's and co-authors (2012) concept, characterise personal and social skills. According Hansen \& Larson (2005) concept this item relates to the scale "Cognitive skills".

Similarly, an item related to focusing attention was removed from the scale "Initiative"; however, this item is one of the key items in Larson's (2000) concept of initiative development. Thus, the initiative of students in Latvia is characterized by only two items (Table 3), which were assessed the highest. The average result of scale evaluation is the highest for the scales of positive experience $-2.72 \pm 0.79$, but, according to the concept of the YES-S, high evaluations of all 4 items are significant, which means constructive initiative (MacDonald et al., 2012). This scale also requires more research.

Following the results, 2 separate factors were obtained, which were called "Social skills" according to MacDonald's concept and "Feedback". We believe 
that it is good that the items related to feedback were divided into a separate factor. Noting the importance of feedback in improving achievements, Professor John Hattie (2009) emphasizes that the feedback to the teacher about what the student is able and is not able to do is very important. It is essential to ensure that mistakes are welcomed, because they have an important role in improving learning. However, students in Latvia rated item "I became better at giving feedback" during physical education as one of the lowest $-2.31 \pm 0.75$. The factor "Social skills" consists of only 6 items. 8 items were removed, considering item loading and the possibility of factor interpretation. Thus, the evaluation provided by students in Latvia for the items of the scale "Personal \& Social skills" only partially correspond to MacDonald's and co-authors (2012) concept.

The obtained factor "Goals setting" was similar with the YES-S instrument, including all 4 items. Athletes often set special goals in the field of sports (Burton \& Weiss, 2008). Setting personal goals increases the motivation to participate in physical activity (Flintoff \& Scraton, 2001; Lewis, 2014). Traditionally, it was considered that all activities are given meaning, direction, and purpose, and that the quality and intensity of behaviour will change as these goals change (Covington, 2000).

The factor "Negative experience" combined 6 of the 10 proposed items. The highest rated items were related with sayings by peers and adults. The verbal abuse from teachers, as well as the aggressive behaviour of peers, which may lead to various expressions and gestures, are the negative experience in sport environment (Brooks \& Magnusson, 2006; Beltrán-Carrillo et al., 2012); however, there is a lot more negative experience in physical education (Flintoff \& Scraton, 2001; Allender et al., 2006; Brooks \& Magnusson, 2006; Rubana \& Ābele, 2008; Strean, 2009, Beltrán-Carrillo et al., 2012, Cardinal et al., 2013). Although many criteria of negative experience were not offered for evaluation, the average result of negative experience exceeds 2 points on a 4-point scale $2.11 \pm 0.67$. The negative attitude towards physical education at school is reflected by often exemptions from sport activities at school in Latvia. (Šišlova \& Fernāte, 2017).

\section{Conclusion}

In conclusion, a five-factor structure was developed, which includes 20 items. The factor loads of the other 17 items indicated that these items were not compatible with the theoretical concept of the YES-S. The created structure differed from the proposed YES-S structure. It was not included the factor "Cognitive skills", as well as the obtained factors split MacDonald's and coauthors (2012) concept of personal and social skills - 2 factors were obtained 
called "Social skills" and "Feedback". The factors "Negative experience”, "Goals setting" and "Initiative" were obtained similarly to the YES-S factor structure.

\section{Acknowledgments}

We thank our colleagues from Centres of Sport of Riga Technical University, Jāzeps Vìtols Latvian Academy of Music and Latvia University of Agriculture, as well as students from University of Latvia for support in data collection. We also thank the all universities students for their participation in this research.

\section{References}

Ajzen, I. (1991). The Theory of Planned Behavior. Organizational Behavior and Human Decision Processes, 50, 179-211.

Allender, S., Cowburn, G. \& Foster, C. (2006). Understanding participation in sport and physical activity among children and adults: a review of qualitative studies. Health Education Research, Theory \& Practice, 21(6), 826-835.

Beltrán-Carrillo, B. J., Devís-Devís, J., Peiró-Velert, C. \& Brown, David H. K. (2012). When Physical Activity Participation Promotes Inactivity: Negative Experiences of Spanish Adolescents in Physical Education and Sport. Youth \& Society, 44(1), 3-27.

Brooks, F. \& Magnusson, J. (2006). Taking part counts: adolescents' experiences of the transition from inactivity to active participation in school-based physical education. Health Education Research, Theory \& Practice, 21(6), 872-883.

Burton, D. \& Weiss, C. (2008). The fundamental goal concept: the path to process and performance success, T.S. Horn (Ed.) Advances in sport psychology ( $3^{\text {rd }}$ ed.) (pp. 340375). Human Kinetics, Champaign, IL.

Cardinal, B. J., Yan, Z. \& Cardinal, M. K. (2013). Negative Experiences in Physical Education and Sport: How Much Do They Affect Physical Activity Participation Later in Life? Journal of Physical Education, Recreation \& Dance, 84(3), 49-53.

Costello, A. B. \& Osborne, J. W. (2005). Best practices in exploratory factor analysis: Four recommendations for getting the most from your analysis. Practical Assessment, Research and Evaluation, 10(7), 1-9.

Covington, V. (2000). Goal Theory, Motivation, and School achievement: An Integrative Review. Annu. Rev. Psychol., 51, 171-200.

Dwyer, T. \& Sallis, J. F., Blizzard, L., Lazarus, R., Dean, K. (2001). Relation of academic performance to physical activity and fitness in children. Pediatric Exercise Science, 13, 225-237.

Eccles, S. \& Barber, B. L. (1999). Student council, volunteering, basketball, or marching band: what kind of extracurricular involvement matters? Journal of Adolescent Research, 14, 10-43.

Flintoff, A. \& Scraton, S. (2001). Stepping into active leisure? Young women's perceptions of active lifestyles and their experiences of school physical education. Sport Education and Society, 6(1), 5-21.

Fraser-Thomas, J. L., Côté, J. \& Deakin, J. (2005). Youth sport programs: an avenue to foster positive youth development. Physical Education and Sport Pedagogy, 10, 19-40.

George, D. \& Mallery, P. (2003). SPSS for Windows step by step: A simple guide and reference. 11.0 update (4th ed.). Boston: Allyn \& Bacon, p. 231. 
Hansen, D. M., \& Larson, R. (2005). The youth experience survey 2.0: Instrument revisions and validity testing. Unpublished manuscript, University of Illinois at UrbanaChampaign. http://web.aces.uiuc.edu/youthdev/

Hattie, J. Visible Learning: a Synthesis of over 800 Meta-Analyses Relating to Achievement. London, New York: Routledge

Health position paper. (2015). Association of Physical Education, http://www.afpe.org.uk/ physical-education/wpcontent/uploads/afPE Health Position Paper Web Version2015.pdf

Hoseinzadeh, D. \& Shoghi, B. (2013). The Relationship between Physical Function and General Health with Academic Achievement. Procedia - Social and Behavioral Sciences, 9(84), 1212-1216.

Korolova, I. (2010). Studentu un vidējo profesionālo iestāžu audzēkņu aptauja [Students and vocational education students survey results]. Rīga: LU FSI, http://www.fsi.lu.lv/ userfiles/Aptaujas_rezultatu_atskaite.pdf

Larson, R. (2000). Toward a Psychology of Positive Youth Development. American Psychological Association, I (55), 170-183.

MacDonald, D. J., Côté, J. Eys, M. \& Deakin, J. (2012). Psychometric properties of the youth experience survey with young athletes. Psychology of Sport and Exercise, 13(3), 332-340.

Norman, G. R. \& Streiner, D. L. (1994). Biostatistics: The bare essentials. St. Louis, MO: Mosby, p. 139.

Rubana, I. M. \& Ābele, A. (2008). Skolas vecuma bērnu attieksme pret sporta stundām, sporta stundu apmeklējums un daži veselības indikatori. [School-Age Children Attitude Towards Physical Education, Attendance of Sports Classes and Some Health Indicators]. RTU zinātniskie raksti, Humanitārās un sociālās zinātnes. Rīga, 8(14), 81-88.

Šišlova, E. \& Fernāte, A. (2015). Studentu attieksmes pret obligātajām fiziskajām aktivitātēm izmaiņas studiju procesā [Changes of Students Attitude towards Compulsory Physical Activity in Study Process]. Humanitārās un sociālās zinātnes, 22, RTU, 26-36.

Šišlova, E. \& Fernāte, A. (2016). Students' Attitudes towards Compulsiry Physical Activities at University. In: Daniela, L., Rutka, L. (Eds). Selected Papers of the Assotiation for Teacher Education in Europe Spring Conference, 2015 (pp. 323-339). Cambridge Scholars Publishing LTD.

Šišlova, E. \& Fernāte, A. (2017). Medical Certificates for Exemption from Compulsory Study Cours "Sports" at University: Problems and Solutions. LASE Journal of Sport Science, 8(1), 3 - 19.

Strean, W. B. (2009). Remembering instructors: Play, pain and pedagogy. Qualitative Research in Sport and Exercise, 1(3), 210-220.

Subramaniama, P. R. \& Silverman, S. (2007). Middle school students' attitudes toward physical education, Teaching and Teacher Education, 23, 602-611.

Vecenāne, H. \& Fernāte, A. (2012). Studentu dzīvesveida raksturojums - situācijas izpēte Latvijā. [Characteristics of Students Lifestyle - Study of the Situation in Latvia]. LSPA Zinātnisko un metodisko rakstu kräjums, 2-14. http://www.lspa.eu/files/research/ 2012/2012_Fernate_2_14.pdf

Шишлова, Э. А. \& Дунай, В. И. (2017). Отношение студенческой молодежи к учебной дисциплине “Физическая культура" [Undergraduate youth attitude towards the academic discipline "Physical Culture”]. В Материалах XV Международной научной сессии по итогам НИР за 2016 год, посвященной 80-летию университета “Научное обоснование физического воспитания, спортивной тренировки и подготовки кадров по физической культуре, спорту и туризму”, Минск: БГУФК, 3, 265-269. 